\title{
Kint és bent háromszor ${ }^{1}$
}

\author{
BALÁZS ANDRÁS ${ }^{2}$
}

A négy határmenti településen zajló kutatás eredményeit közreadó tanulmány azt a kérdést járja körül, hogy a peremhelyzetü gazdasági térségekben milyen együttélési formációk, munkamegosztási gyakorlatok jöttek létre a rendszerváltás után. Vagyis, hogy a gazdasági szerkezetváltozás következtében jelentőségüket vesztő mezőgazdasági és ipari központok vonzáskörzetében található települések hogyan rendeződtek át demográfiai, etnika és életszervezési szempontból, illetve hogy az egyes társadalmi csoportok boldogulásában milyen mértékben meghatározó az informális gazdaságban való részvétel.

A szerzők a településtípusok leírásával arra keresik a választ, hogy az átalakuló körülmények miként befolyásolták a határmenti községek ${ }^{3}$ lakóinak identitását, a kooperációk és kizárások mechanizmusai milyen szerepet játszanak a falusi szomszédságok hétköznapjaiban. A társadalmi folyamatok vizsgálata nem elsősorban a kultúrára, sokkal inkább a közösségi szerveződés formáira koncentrál. A peremhelyzet hármassága - országhatár, etnikai határok, az informális gazdaság határai - ha különbözőképpen is, de a vizsgált települések mindegyikére hatással van.

\section{Módszertan}

A tanulmánykötet kiterjesztett esettanulmányok összegzésének tekinthető, amely vegyes módszertant alkalmaz. A közösségkutatás az egyes helyszíneket alulról közelíti meg: a helyi elittel való kapcsolatfelvételt megelőzően a kérdezők véletlenszerűen kiválasztott házakhoz látogattak el. Az intézményi interjúk a háztartásfőkel készített beszélgetéseket egészítik ki. A kutatók az interjúk és egyéb források feldolgozása során az esetszintủ megértésre törekedtek. A helyi megélhetési formák, a határmegvonó és határátlépési gyakorlatok logikáját az egyes interjúalanyok életútján keresztül ismerhetjük meg.

${ }^{1}$ Kovács Éva - Vidra Zsuzsanna - Virág Tünde (2013): Kint és Bent - Lokalitás és etnicitás a peremvidékeken. 'Harmattan Kiadó, Budapest.

${ }^{2}$ Debreceni Egyetem, Humán Tudományok Doktori Iskola Szociológia és társadalompolitika doktori program, doktorandusz.

${ }^{3}$ A kutatás helyszíneit Old, Mocsa, Bedő, valamint Tiszakerecseny községek alkotják. 


\section{OLVASS FELESLEGESET!}

A tanulmánykötet módszertani sajátossága, hogy a helyi viszonyok bemutatását több dimenzióban végzi el: Miközben feltárja a települések demográfiai szerkezetének átalakulása mögött álló migrációs stratégiák mozgatórugóit, esettanulmányokkal illusztrálja a helyi társadalom átformálódását. Az interjúrészletek elemzése pedig érzékenyen világít rá a községi identitás és etnikus reprezentáció változásaira.

\section{Az informális gazdaság szerepe}

A települések lakóinak megélhetési stratégiáit vizsgálva a kutatók arra voltak kíváncsiak, hogy a községeket alkotó társadalmi csoportok boldogulásában milyen mértékben meghatározó az informális világban való részvétel ${ }^{4}$.

A négy falu lakosságának jövedelemstruktúráját összevetve világossá vált, hogy az egyes háztartások tisztán piacról származó bevételei elenyészőek. Az államtól érkező forrásokkal elsősorban a közalkalmazottak és a nyugdíjasok rendelkeznek. A vegyes bevételi források - társadalmi és foglalkozási státusztól függetlenül - a vizsgált községek valamennyi csoportjánál megtalálhatóak.

A peremhelyzetű gazdasági térségek településeire egységesen jellemző, hogy a gazdálkodás és munkamegosztás viszonyaira az önkormányzat jelentős befolyást gyakorol. A polgármesteri hivatal és a hozzá kapcsolódó intézmények mellett a közfoglalkoztatás munkaerőigénye a helyi társadalom domináns alakítója. A települési vezetők nem ritkán a közmunkaprogramokon keresztül érvényesítik hatalmi érdekeiket.

A háztájizás során megtermelt javak elsősorban a kiegészítés, a közösségen belüli cserék és az önreprezentáció eszközei. A jószágtartás a gazdasági racionalitás helyett fóként státuszszimbólumként van jelen. A kisparaszti hagyományok ápolása, valamint a Kádár-korszak munkás világához kapcsolódó nosztalgia az újonnan betelepülőkkel szembeni - gyakran etnikus színezetű - határmeghúzás része.

Az informalitás jelenlétét településenként vizsgálva a kutatók arra jutottak, hogy Oldon valamennyi társadalmi csoport fenntart informális kapcsolatokat. Az informális piaci szolgáltatásokból és a cserealapú szerveződésekből származó jövedelmek (fuvarozás, cselédkedés, feketepiacozás stb.) mellett gyakran az idénymunkák résztvevőit is kisebb adományokkal, „zsebbe adott pénzzel” fizetik ki. Kirajzolódik azonban egy hierarchikus rendszer: míg a magasabb státuszú családok kevésbé

\footnotetext{
${ }^{4}$ Az informális gazdaság és a hozzá kapcsolódó tevékenységek kutatása Keith Hart szociálantropológus tevékenységéhez kötődik (Hart 1973). A fejlett világ országainak vizsgálatakor hagyományosan azokat a pénzkereseti lehetőségeket tekintik az informális gazdaság körébe tartozónak, amelyek valamilyen módon elkerülik a hatósági szabályozást, egyben az állam által nyújtott védelmet sem élvezik (Castells Portes 1989, Feige 1990). Ebben a megközelítésben nem válik el egymástól az informális és az illegális kategóriája: az adott társadalmi kontextus dönti el a tevékenység minősítését.
} 


\section{OLVASS FELESLEGESET!}

vesznek részt az informális gazdaságban, addig a legalacsonyabb státuszú háztartások nagyobb mértékben finanszírozzák magukat informális forrásokból.

A legelszigeteltebb helyzetű Tiszakerecseny esetében a szegény családoktól a helyi középosztályig mindenki az informális világban igyekszik boldogulni. Számos családban a "tőkefelhalmozás” alapjait a kilencvenes években folytatott csempészet teremtette meg, némelyek informális kapcsolatrendszerüknek köszönhetően vették ki részüket a földprivatizációból. A faluba visszatért aszfaltozó családok a korábban jövedelmező építőipari munkákból szorultak ki többé-kevésbe teljesen. Előbbi tevékenység virágzása idején sem feltétlenül jelentett legális alkalmazást, mára legfeljebb egy-két hónapos alkalmi munkát biztosít a fővárosban. Kizárólag formális kapcsolatokkal csupán a falu egyetlen nagyvállalkozója, illetve a közalkalmazottak rendelkeznek.

A méreténél fogva leginkább rétegzettnek tekinthető Mocsán a legalacsonyabb és a legmagasabb státuszú csoportok bírnak informális kapcsolatokkal. A helyi nagyvállalkozók „ügyeskedése” mellett Mocsán a segélyekből, alkalmi munkákból elő háztartások érintkeznek az informális világgal. E családokban keverednek a formális és informális, állami és piaci bevételek, s itt találjuk mindazokat, akik az illegális határt átlépve jutnak egyéb forrásokhoz (pl. orvhalászat).

Hasonló mintázatot mutat Bedő is, azzal az eltéréssel, hogy a községben a legmagasabb státuszúakra jellemző az illegalitással való érintkezés. A helyi munkanélkülieknek és közmunkásoknak elsősorban a mezőgazdasághoz kapcsolódó kisegítő tevékenységekből származik kiegészítő jövedelme.

Általánosságban megállapítható, hogy azokon a településeken, ahol a piaci mechanizmusok vagy pályázati források szerephez jutnak, ott az előnyök megszerzése érdekében a középosztály és az elitek mozognak az informális világban. Minél távolabb kerülünk azonban a kiszámítható munkajövedelmek világától, annál inkább az informalitás szövi át a helyi társadalom mindennapjait.

\section{Demográfia és migráció}

Noha valamennyi vizsgált település az országhatárhoz közel fekszik, a helyi és regionális különbségek miatt az elmúlt évtizedekben eltérő migrációs stratégiák váltak meghatározóvá5. A migrációnak két domináns formája figyelhető meg a településeken: a munkaerőpiaci migráció, amikor az egyének, illetve családok a megélhetés

${ }^{5}$ A munkaerőpiaci migráció klasszikus elméleteiben a migrációt magyarázó legfontosabb változó az egyén és a rokonság korábbi migrációs tapasztalata: a kibocsátó és céltelepülések közötti kapcsolatot a bevándorló hálózatok újratermelése tartja fenn. Azok tudnak tehát leginkább kimozdulni születési helyükről, akik ugródeszkaként képesek használni baráti, rokoni ismeretségeiket (Massey 1987, Taylor 1986). 


\section{OLVASS FELESLEGESET!}

miatt váltanak lakóhelyet, valamint a képzési migráció, amikor a magasabb iskolai végzettség megszerzése okán hagyják el születési helyüket.

A lehetőségek és erőforrások beszűkülése miatt az oldi családok már a szocialista korszakban arra törekedtek, hogy a gyermekeik a megyén belül próbáljanak boldogulni. A rokonsági rendszer közelsége jelentősen csökkentette a költözés költségeit és kockázatait. Az elöregedő és elnéptelenedő faluba a telepfelszámolásokat követően a környékbeli romák költöztek be, akik azonban jóval szerényebb mobilitással bírnak. A generációs elvándorlás és a roma családok betelepülésének köszönhetően Oldon lezártnak tekinthető az etnikai csere.

Bedő a rendszerváltás időszakában került periférikus helyzetbe, ám a falut érintő migrációs nyomás etnikai hovatartozástól függetlenül nehezedett a lakókra. Elérhető munkalehetőség hiányában a helyi lakosság jelentős része a fővárosban próbált szerencsét. Mindezt megelőzte egy felhalmozási szakasz, amikor csupán a férjek, illetve fiatal felnőttek igyekeztek tőkére szert tenni a kétlaki élettel.

Tiszakerecseny és Mocsa esetében már a hatvanas-hetvenes években jelentős ingázás kezdődött, mely azonban nem eredményezett végleges elköltözést. Tiszakerecsenyben az ingázó életforma a roma vállalkozói réteg („aszfaltozók”) esetében általánossá vált. A gazdasági válságok idején egyfajta „visszatorlódás” figyelhető meg, amely további szociális és etnikai feszültségeket eredményez a községen belül.

A vizsgált települések közül - a környékbeli ipari központok közelség miatt egyedül Mocsa tudta megtartania népességreprodukciós képességét. Mocsáról csak annak kellett kimozdulnia, aki közép- vagy felsőfokú intézményben akart továbbtanulni. Bár Bedőnek jelentős esélye mutatkozik arra, hogy idővel Nagyvárad agglomerációs településévé váljon, a tősgyökeres helyiek többsége - köztük az egykori roma lakosság - véglegesen elhagyta a falut. Old es Tiszakerecseny mára visszafordíthatatlanul a perifériára szorult, az ott élők menedékként, „depóként” használjak községeket.

\section{A helyi foglalkoztatás sajátosságai}

A helyi közösség egzisztenciális boldogulására a rendszerváltást követően három formában nyílt lehetőség: a mezőgazdasági termelésbe való bekapcsolódás mellett csupán a települések intézményeiben történő munkavállalás, illetve a közmunka biztosítja a létfenntartáshoz szükséges bevételeket. A határ közelsége miatt a kilencvenes évek elején a bevételforrásokat a jövedéki termékekkel való kereskedés, valamint a benzincsempészés egészítette ki. A bevásárló turizmust leszámítva, az országhatár idegenforgalmi szempontból csupán Bedő esetében játszik szerepet.

A szezonális mezőgazdasági munkáknál az önkormányzat intézményeinél való munkavállalás, illetve a közfoglalkoztatás ugyan kiszámíthatóbb megélhetést garan- 


\section{OLVASS FELESLEGESET!}

tál, ám a forráselosztás és munkaerő-kiválasztás sajátosságai miatt ez az alternatíva csak egy szúk réteg számára nyitott. A községi vezetők lényegében egy személyben határoznak a helyi szociálpolitika és humánerőforrás-gazdálkodás valamennyi kérdéséről. Ennek megfelelően a közfoglalkoztatásban résztvevő személyek kiválasztása szelektív és kirekesztő. Az önkormányzati intézményekben és az idősgondozásban szinte kizárólag a helyi vezetőkhöz közel álló, „megbízható” személyek dolgozhatnak ${ }^{6}$.

A tanulmány szerzői a helyi viszonyok vizsgálata során arra jutottak, hogy a társadalmi integráció bizonyos korlátozott formáit a helyi mezőgazdasági vállalkozók teremtik meg. A kutatás során felvett interjúk Tiszakerecseny esetében például arról számolnak be, hogy a munkaadók többsége etnikai hovatartozástól függetlenül alkalmaz napszámosokat. Mivel a mezőgazdasági vállalkozók maguk is kiszolgáltatottak a bérmunkásoknak, a bevált munkaerővel személyesebb viszonyra törekednek. A községi gazdasági elit integrációs törekvéseit azonban hiba volna túlbecsülni: ugyan a helyi szegényközösség egy részét legalább idényjelleggel bevonják a községi munkamegosztásba, ám e „patrónus-kliens” rendszer a hierarchikus viszonyokat is konzerválja.

\section{Harc a közösségi terekért}

A feltáró esettanulmányok a megélhetésért folytatott megküzdési stratégiák mellett a felszín alatt zajló társadalmi folyamatokat is bemutatják. A vizsgált települések egy részében a tôsgyökeres polgárok és a demográfiai többséget alkotó roma családok között egyfajta szimbolikus harc zajlik a közösségi terekért. Az adott község telepi jellegű részéről (vagy romák lakta utcáiból) a falumag irányába beköltöző lakosságot az évtizedek óta ott élő helyiek nem tudják visszatartani, hiszen nem akad más, aki megvásárolná az üresen álló belterületi ingatlanokat. Hasonló a helyzet az érintett települések iskoláiban is: a roma gyermekek számszerű többségét kénytelen-kelletlen elviselik a többségi szülők, mivel az intézmények a kisebbségi fiatalok nélkül fenntarthatatlanok lennének.

A fenti folyamatot a kutatók beszámolói szerint a rendszerváltást követően felerősödő szelektív migráció tovább erősítette. A '89 után bekövetkező társadalmiterületi egyenlőtlenségeket felismerve a középrétegek piacképes szaktudással rendelkező része fokozódó intenzitással hagyta el szülőfaluját, illetve igyekezett gyermekei számára a földrajzi mobilitás lehetőségeit megteremteni. Ezzel párhuza-

${ }^{6}$ A közfoglalkoztatás társadalom- és piactorzító hatásainak részletes megismeréséhez érdemes elolvasni Messing Vera Kettévágott munkapiac, szétforgácsolt társadalom című tanulmányát (Messing 2012). 


\section{OLVASS FELESLEGESET!}

mosan a falut elhagyó családok helyére alacsonyabb státuszú, jellemzően a nagyvárosokból kiszoruló szegénycsaládok vándoroltak be ${ }^{7}$.

Ugyan az eltelt évek alatt egyre nagyobb számban fogyó „őslakosok” erős csoporttudattal, hasonló társadalmi, gazdasági és kulturális jellemzőkkel rendelkeznek, létszámukat tekintve vesztésre állnak. Vezető szerepük megőrzése kétféle okkal magyarázható. Egyrészt a helyi gazdasági és politikai kulcspozíciók mindegyikét a többségi polgárok birtokolják, másrészt az újonnan beköltözők etnikailag homogénnek tekinthetőek, valójában azonban egy rendkívül sokszínű csoportot alkotnak.

\section{Összefoglalás}

A formális és informális megélhetési technikák leírása során az esettanulmányok egy része a helyi szinergiák, a többségi és kisebbségi lakosok közötti békés munkamegosztás eredményeiről számol be. Ennek ellenére érdemes elgondolkodnunk a peremhelyzetű térségek hosszabb távú perspektíváiról.

Bár a kutatás időszakában az etnikailag vegyes összetételű községekben egyfajta egyensúlyi helyzet állt fenn a kulcspozíciókat betöltő nem-romák és a demográfiai többséget jelentő cigányság között, azonban e status quo nem ad megnyugtató választ a jövőt illetően. A községek társadalmi békéjét nem lehet tartósan a helyi nagygazdák racionális és tisztességes munkaadói magatartására alapozni. Kérdés, hogy milyen jövő előtt állnak azok a szegregálódó települések és kistérségek, ahonnan a piaci szereplők és az állami intézményrendszer közel egy évtizede kivonult.

A rendszerváltás utáni változásokkal, a munkalehetőségek hirtelen beszúkülésével a tősgyökeres és betelepülő családok is csapdahelyzetbe kerültek: elköltözni - az elértéktelenedő ingatlanok és érdemi megtakarítások híján - nem tudnak, a helyi boldogulás lehetetlenné vált. A kifelé irányuló munkavállalás bizonytalanabb és kiszolgáltatottabb helyzetet teremt, mint az elmúlt évtizedekben bármikor.

\section{Irodalom}

Castells, Manuel - Portes, Alejandro (1989): World Underneath: The Origins, Dynamics and Effetcs of the Informal Economy. In: Portes, Alejandro - Castells, Manuel (eds.): The Informal Economy: Studies in Advanced and Less Developed Countries. L. A. Banton, Baltimore, MD, The Johns Hopkins University Press: 208-227.

${ }^{7}$ A szegregálódó térségek kialakulásának új mintáiról a kétezres évek közepétől születtek átfogó munkák (Ladányi - Szelényi 2004, Virág 2010). 
www. metszetek.unideb.hu

\section{OLVASS FELESLEGESET!}

Feige, Edgar L. (1990): Defining and Estimating Underground and Infromal Economies: New Institutional Economics Approach. World Development 18(7): 9891002.

Hart, Keith (1973): Informal Income Opportunities and Urban EmpolymentinGhana. Journal of Modern African Studies, 11(2): 61-89.

Ladányi János - Szelényi Iván (2004): A kirekesztettség változó formái. Napvilág Kiadó, Budapest

Massey, Douglas (1987): Understanding Mexican Migration to the United States. American Journal of Sociology, 92: 1372-1403.

Messing Vera (2012): Kettévágott munkapiac, szétforgácsolt társadalom. In: Kovách Imre - Dupcsik Csaba - P. Tóth Tamás - Takács Judit (szerk.): Társadalmi integráció a jelenkori Magyarországon. MTA Társadalomtudományi Kutatóközpont, Budapest: 204-220.

Taylor, Edward J. (1986): Differential Migration, Networks, Information and Risk. Research in Human Capital and Development, 4: 147-171.

Virág Tünde (2010): Kirekesztve - Falusi gettók az ország peremén. Akadémiai Kiadó, Budapest 